\title{
IDENTIFIKASI PEMAFAATAN ALAT PERMAIAN EDUKATIF (APE) DALAM MENGEMBANGKA MOTORIK HALUS ANAK USIA DINI
}

\author{
Baik Nilawati Astini, Nurhasanah, Ika Rachmayani, I Nyoman Suarta \\ Universitas Mataram \\ nilaastini@vmail.com, nurhasanahmohali@gmail.com, \\ ika.rachma3@gmail.com,suarta9@gmail.com
}

\begin{abstract}
Abstrak
Pendidikan anak usia dini adalah salah satu lembaga pendidikan yang memegang peran penting untuk membantu pemerintah mempersiapkan generasi muda sedini mungkin, yang sesuai dengan tujuan pendidikan anak usia dini yaitu membantu meletakkan dasar kearah perkembangan sikap perilaku, pengetahuan, keterampilan dan daya cipta yang diperlukan oleh anak didik. Penelitian ini pada hakekatnya bertujuan untuk memberikan gambaran yang lebih mendalam tentang Analisis Identifikasi Pemafaatan Alat Permainan Edukatif (APE) Dalam Mengembangkan Motorik Halus Anak Usia Dini. Dimana hasil penelitian ini pada akhirnya diperoleh data yang menggambarkan Analisis Identifikasi Pemafaatan Alat Permainan Edukatif (APE) Dalam Mengembangkan Motorik Halus Anak Usia Dini. Berdasarkan data yang diperoleh menunjukan bahwa APE yang banyak digunakan atau dimanfaatkan guru untuk stimulasi tumbuh kembang motorik halus anak adalah bahan alam yang terdiri dari barang bekas seperti kertas bekas yang akan di sobek dan dibuat bubur kertas $88,8 \%$. Tetapi pemanfaatan Koran bekas yang lebih mudah untuk dibentuk dan diekmbangkan pada kegiatan dan stiulasi asek lain maah jarang digunakan $(33,3 \%)$ Bahan alam yang mudah didapat seperti serbuk gergaji, pasir dan air dan sejinisnya $83,3 \%$ guru sangat sering menggunakannya dalam proses pembelajaran. Hal yang juga sering dimanfaatkan guru adalah meronce manic-manik yakni $72,2 \%$, alat mencocok $77,8 \%$.
\end{abstract}

Kata kunci: APE, motorik halus

\section{IDENTIFICATION OF EDUCATIONAL EDUCATION EQUIPMEN APPLICATION (APE) IN DEVELOPING SMOOTH MOTOR EARLY CHILDHOOD}

\begin{abstract}
Early childhood education is one of the educational institutions that plays an important role to help the government prepare young generation as early as possible, in accordance with the purpose of early childhood education that helps lay the groundwork towards the development of behavioral attitude, knowledge, skills and creativity required by the students. This research essentially aims to provide a more in-depth description of the Identification Analysis of Educational Game Device Gaming (APE) in Developing Smooth Motorics of Early Childhood. Where the results of this study ultimately obtained data describing the Identification Analysis of Educational Game Utilization Equipment (APE) In Developing Smooth Motorik Anak Early Childhood. Based on the data obtained shows that the APE is widely used or used by teachers to stimulate the growth of fine motor development of children is a natural material consisting of secondhand goods such as waste paper that will be torn and made pulp $88.8 \%$. However, the use of used newspapers that are easier to establish and to be used in other activities and stiulations of asek are rarely used (33.3\%) Suitable natural materials such as sawdust, sand and water and $83.3 \%$ of the teachers use it very often in the process Learning. It is also often used by the teacher is meronce manic-beads that is $72.2 \%, 77.8 \%$ match tool.
\end{abstract}

Keywords: APE, fine motor 


\section{PENDAHULUAN}

Pendidikan anak usia dini adalah salah satu lembaga pendidikan yang memegang peran penting untuk membantu pemerintah mempersiapkan generasi muda sedini mungkin, yang sesuai dengan tujuan pendidikan anak usia dini yaitu membantu meletakkan dasar kearah perkembangan sikap perilaku, pengetahuan, keterampilan dan daya cipta yang diperlukan oleh anak didik. Alat Permainan edukatif bagi anak adalah alat main yang dapat menstimulasi panca indra dan kecerdasan anak, yang meliputi indra penglihatan penciuman, pengecapan, perabaan dan pendengaran. Ape sangat variatif dan tidak harus yang mahal. Kita bisa membuat sendiri dengan memanfaatkan benda-benda yang ada disekitar kita. Misalnya kotak-kotak bekas, botol-botol plastik yang disusun, atau bahan dari kertas, karet, buah dan tanarnan. Kegiatan bermain air dan pasir juga bisa dimanfaatkan sebagai permainan edukatif caranya biarkan sikecil memasukan air dan pasir ke dalam wadah tertentu dengan menggunakan mangkuk atau gayung. Semua itu akan melatih hampir semua kemampuan dasar anak yang dapat menyentuh bagian kognitif, afektif dan psikomotoriknya. Pentingnya pemanfaatan APE yang digunakan di lembaga PAUD dalam mengembangkan motorik halus anak usia 5-6 tahun, maka peneliti tertarik untuk mengangkat judul "Identifikasi Pemanfaatan Alat Permainan Edukatif (APE) dalam Mengembangkan Motorik Halus Anak". Sehingga, perlunya melakukan identifikasi APE apa saja yang digunakan dalam Mengembangkan Motorik Halus Anak Usia Dini dan sesuai dengan syarat-syarat Alat permainan Edukatif Anak Usia Dini.

Dengan tujuan untuk Mengidentifikasi APE apa saja yang digunakan dalam Mengembangkan Motorik Halus Anak Usia dini dan sesuai dengan syarat-syarat APE Anak Usia dini. Hal ini senada dengan pendapat Mayke Sugianto (dalam Wiyani dkk, 2012:149) mengemukakan setiap APE dapat difungsikan secara multiguna.
Walaupun masing-masing alat permainan memiliki kekhususan untuk mengembangkan aspek perkembangan tertentu, tidak jarang satu alat permainan dapat meningkatkan lebih dari satu aspek perkembangan. Misalnya, mainan balokbalokan bangunan dalam berbagai macam ukuran serta dengan warna yang disukai anak. Balok-balok dapat disusun sesuai kehendak anak, baik berasarkan ukuran maupun berdasarkan warna tertentu (Zaman dkk, 2007:5)

Adams (1975) berpendapat bahwa permainan edukatif adalah semua bentuk permainan yang dirancang untuk memberikan pengalaman pendidikan atau pengalaman belajar kepada para pemainnya, termasuk permainan tradisional dan moderen yang diberi muatan pendidikan dan pengajaran. Sehingga, dapat disimpulkan bahwa alat permainan edukatif adalah alat permainan yang sengaja dirancang khususnya untuk menunjang terselenggaranya pembelajaran anak secara efektif dan menyenangkan, serta sebagai sarana yang dapat merangsang aktivitas anak untuk mempelajari sesuatu tanpa anak menyadarinya dan yang dirancang secara multiguna sehingga anak dapat melatih berbagai motorik halus, mengenal konsep warna, bentuk dan ukuran. Dan Alat Permainan Edukatif (APE) merupakan alat permainan untuk anak usia dini yang dapat mengoptimalkan perkembangan anak, yang dapat disesuaikan penggunaannya menurut usianya dan tingkat perkembangan anak yang bersangkutan.

Untuk dapat melihat dan memahami secara lebih mendalam mengenai apakah suatu alat permainan dapat dikategorikan sebagai alat permainan edukatif untuk anak TK atau tidak, terdapat beberapa ciri yang harus dipenuhinya yaitu: a. Alat permainan tersebut ditujukan untuk anak TK. b. Difungsikan untuk mengembangkan berbagai perkembangan anak TK. c. Dapat digunakan dengan berbagai cara, bentuk, dan untuk bermacam tujuan aspek pengembangan atau bermanfaat multiguna. 
d. Aman atau tidak berbahaya bagi anak. e. Dirancang untuk mendorong aktivitas dan kreativitas anak. f. Bersifat konstruktif atau ada sesuatu yang dihasilkan mengandung nilai pendidikan.

Alat permainan edukatif (APE) untuk anak TK selalu dirancang dengan pemikiran yang mendalam tentang karakteristik anak dan disesuaikan dengan rentang usia anak TK. APE untuk tiap kelompok usia dirancang secara berbeda. Untuk anak pada rentang usia 2-4tahun tentunya berbeda dengan APE untuk anak pada rentang usia 4-6 tahun. Sebagai contoh dalam pembuatan Puzzle. Puzzle merupakan salah satu jenis APE yang menarik untuk diperkenalkan kepada anak TK. Puzzle untuk anak usia 2-4 tahun memiliki bentuk sederhana dengan potongan atau keping puzzle yang sederhana pula dan jumlahnya pun tidak terlalu banyak. Berbeda dengan puzzle untuk anak usia 4-6 tahun jumlah kepingannya lebih banyak lagi.

Oleh karena itu sangatlah jelas bahwa APE dirancang dan ditujukan untuk anak dengan mempertimbangkan karakteristik perkembangannya termasuk masalah perbedaan usia. Perbedaan rentang usia anak menjadi hal yang sangat fondasional untuk diperhatikan karena perbedaan usia berpengaruh terhadap tahap perkembangan dan kemampuan yang dimiliki anak. APE juga difungsikan untuk mengembangkan berbagai aspek perkembangan anak usia dini Aspek-aspek yang dikembangkan meliputi aspek moral agama, sosial emosional, bahasa, kognitif, fisik-motorik dan seni. APE yang dirancang untuk mengembangkan aspek kognitif biasanya dapat digunakan anak untuk melatih daya nalarnya. APE jenis ini dirancang dengan rancangan tertentu baik dari segi bentuk, ukuran dan warnanya.

APE dirancang dengan memperhatikan tingkat keamanan dan keselamatan anak, misalnya jika menggunakan cat, cat yang digunakan tidak beracun (non toxic) dan tidak mudah mengelupas, jika alat bersudut maka sudut mainan tidak runcing atau harus tumpul agar tidak membahayakan anak. APE juga didesain secara sederhana dan ringan sehingga mudah dibawa dan dijinjing oleh anak. APE juga mendorong anak untuk beraktifitas dan bersifat konstruktif atau menghasilkan sesuatu, berbeda dengan menonton TV atau mendengarkan radio, anak hanya pasif melihat dan mendengarkan. Dengan APE anak dapat berimajinasi dan berkreasi menghasilkan sesuatu misalnya anak yang bermain lego atau membangun balokbalok. APE dan alat yang dipakai dalam membantu proses perkembangan untuk anak Usia dini berguna untuk :

1. Pengembangan aspek fisik, yaitu kegiatan-kegiatan yang dapat menunjang atau merangsang pertumbuhan fisik anak, trediri dari motorik kasar dan halus. Contoh alat bermain motorik kasar : sepeda, bola, mainan yang ditarik dan didorong, tali, dll. Motorik halus: gunting, pensil, bola, balok, lilin, dan lain-lain.

2. Pengembangan bahasa, dengan melatih berbicara, menggunakan kalitnat yang benar. Contoh alat permainan : buku bergambar, buku cerita, majalah, radio, tape, TV, dan lain-lain.

3. Pengembangan aspek kognitif, yaitu dengan pengenalan suara, ukuran, bentuk. Warna, dan lain-lain. Contoh alat permainan: buku bergambar, buku cerita, puzzle, boneka, pensil warna, radio, dan lain-lain.

Alat-alat permainan yang dikembangkan memiliki berbagai fungsi dalam mendukung penyelenggaraan proses belajar anak sehingga kegiatan dapat berlangsung dengan baik dan bermakna serta menyenangkan bagi anak. Fungsifungsi tersebut adalah: a. Menciptakan situasi bermain (belajar) yang menyenangkan bagi anak dalam proses pemberian perangsangan indikator kemampuan anak. b.Menumbuhkan rasa percaya diri dan membentuk citra diri anak yang positif. Pada kegiatan anak memainkan suatu alat permainan dengan tingkat kesulitan tertentu misalnya 
menyusun balok-balok menjadi suatu bentuk bangunan tertentu, pada saat tersebut ada suatu proses yang dilalui anak sehingga anak mengalami suatu kepuasaan setelah melampaui suatu tahap kesulitan tertentu yang terdapat dalam alat permainan tersebut. Proses-proses seperti itu akan dapat mengembangkan rasa percaya secara wajar dimana anak merasakan bahwa tiada suatu kesulitan yang tidak ditemukan penyelesaiannya. c. Memberikan stimulus dalam pembentukan perilaku dan pengembangan kemampuan dasar, APE dapat membantu anak dalam pembentukan perilaku melalui pembiasaan dan pengembangan kemampuan dasar merupakan fokus pengembangan pada anak usia usia dini, sehingga Alat permainan edukatif dirancang dan dikembangkan untuk memfasilitasi kedua aspek pengembangan tersebut. d. Memberikan kesempatan anak bersosialisasi, berkomunikasi dengan teman sebaya. Sehingga, Alat permainan edukatif berfungsi memfasilitasi anak-anak mengembangkan hubungan yang harmonis dan komunikatif dengan lingkungan di sekitar misalnya dengan teman-temannya.

Persyaratan tersebut meliputi syarat edukatif, syarat teknis dan syarat estetika. Penjabaran mengenai syarat-syarat tersebut adalah sebagai berikut: a. Syarat edukatif maksudnya bahwa pembuatan alat permainan edukatif haras disesuaikan dengan program pendidikan yang berlaku sehingga pembuatannya akan sangat membantu pencapaian tujuan-tujuan yang terdapat di dalam program pendidikan yang disusun. Secara lebih khusus lagi syarat edukatif ini maksudnya bahwa: 1 . APE yang dibuat disesuaikan dengan memperhatikan program kegiatan pendidikan (program pendidikan/ kurikulum yang berlaku. 2. APE yang dibuat disesuaikan dengan didaktik metodik artinya dapat membantu keberhasilan kegiatan pendidikan, mendorong aktifitas dan kreatifitas anak dan sesuai dengan kemampuan (tahap perkembangan anak). b.. Syarat teknis
Persyaratan teknis yang haras diperhatikan dalam pembuatan alat permainan edukatif berkaitan dengan hal-hal teknis seperti pemilihan bahan, kualitas bahan, pemilihan warna, kekuatan bahan dalam suhu-suhu tertentu dan lain sebagainya. Secara lebih rinci syarat-syarat teknis dalam pembuatan alat permainan edukatif adalah: 1. APE dirancang sesuai dengan tujuan, fungsi sarana (tidak menimbulkan kesalahan konsep) contoh dalam membuat balok bangunan, ketepatan bentuk dan ukuran yang akurat mutlak dipenuhi karena jika ukurannya tidak tepat akan menimbulkan kesalahan konsep. 2. APE hendaknya multiguna, walaupun ditujukan untuk tujuan tertentu tidak menutup kemungkinan digunakan untuk tujuan pengembangan yang lain. 3. APE dibuat dengan menggunakan bahan yang mudah didapat di lingkungan sekitar, murah atau dari bahan bekas/sisa. 4. Aman (tidak mengandung unsur yang membahayakan anak misalnya tajam, beracun dan lain-lain). 5. APE hendaknya awet, kuat dan tahan lama (tetap efektif walau cahaya berubah). 6. Mudah dalam pemakaian, menambah kesenangan anak untuk bereksperimen dan bereksplorasi. 7.Dapat digunakan secara individual, kelompok dan klasikal. Dan yang terakhir c. Syarat estetika Persyaratan estetika ini menyangkut unsur keindahan alat permainan edukatif yang dibuat. Unsur keindahan/ estetika ini sangat penting diperhatikan karena akan memotivasi dan menarik perhatian anak untuk menggunakannya. Hal-hal yang lebih rinci yang berkaitan dengan syarat estetis ini menyangkut hal-hal sebagai berikut: 1 . Bentuk yang elastis, ringan (mudah dibawa anak). 2.Keserasian ukuran (tidak terlalu besar atau terlalu kecil). 3. Warna (kombinasi warna) serasi dan menarik.

Perkembangan motorik halus anak usia dini lebih ditekankan pada koordinasi gerakan motorik halus dalam hal yang berkaitan dengan kegiatan meletakkan atau memegang sesuatu objek dengan menggunakan jari tangan dimana keterampilan motorik halus memerlukan 
koordinasi mata dan tangan, sehingga gerakan tangan perlu dikembangkan dengan baik yang dapat berguna untuk perkembangan selanjutnya. Perkembangan motorik berarti perkembangan pengendalian gerakan jasmaniah melalui kegiatan pusat syaraf, urat syaraf dan otot yang terkoordinasi, pengendalian tersebut berasal dari perkembangan refleksi dan kegiatan masa yang ada pada waktu lahir sebelum waktu perkembangan itu terjadi anak akan tetap tidak berdaya jadi perkembangan motorik halus adalah proses tumbuh kembang kemampuan gerak seorang anak yang melibatkan gerak otot-otot kecil pada tangan, antara lain meliputi mencoret, menulis, menggambar, meronce manikmanik atau makan sendiri, (Hurlock, 1978 : 150).

Motorik halus adalah pembelajaran bagi anak prasekolah yang berhubungan dengan keterampilan fisik yang melibatkan otot kecil serta koordinasi antara mata dengan tangan yang dikembangkan melalui kegiatan dan rangsangan yang dilakukan secara rutin dan terus manerus seperti menulis, meremas, menggambar, menyusun balok, dan melipat kertas (Decaprio, 2013:20). Dari beberapa pengertian diatas maka dapat disimpulkan bahwa motorik halus adalah keterampilan belajar dengan menggunakan koordinasi otot-otot halus seperti jari-jari tangan dalam berbagai macam kegiatan diantaranya menggambar, mewarnai, menggunting, melipat, dan lain-lain. Belajar motorik juga harus dengan pengawasan dari orang tua agar orang tua dapat mengetahui sejauh mana tahap perkembangan anaknya dalam belajar keterampilan motorik. Denga tujuan pengembangan motorik halus adalah : a. Mampu memfungsikan otot-otot kecil, seperti gerakan jari tangan. b. Mampu mengkoordinasikan kecepatan tangan dengan mata. c. Mampu mengendalikan emosi. Sehingga, pengembangan motorik halus berfungsi sebagai : a. sebagai alat untuk mengembangkan keterampilan gerak kedua tangan. b. Sebagai alat untuk mengembangkan koordinasi kecepatan tangan dengan gerakan mata. c. Sebagai alat untuk melatih penguasaan emosi.

\section{METODE PENELITIAN}

Jenis penelitian yang dipergunakan adalah Jenis penelitian yang digunakan yaitu penelitian deskriptif kualitatif yaitu penelitian yang menghasilkan data berupa kata-kata baik tertulis atau lisan dari orangorang atau prilaku yang diamati (Nurliana, 2012:21). Dengan wilayah penelitian dilakukan di kota Mataram, NTB. Populasi dalam penelitian ini adalah seluruh guru yang mengajar di PAUD Wilayah Kota Mataram terutama guru kelompok usia 5-6 tahun yang memanfaatkan APE khususnya dalam mengembangkan motorik halus. Dengan sampel penelitian 36 orang guru kelompok A dan Kelompok B yang tersebar di lembaga PAUD di wilayah Kota Mataram tempat mahasiswa PG PAUD melaksanakan PPL. Metode pengumpulan data menggunakan metode observasi dan wawancara. Sedangkan analisis data mengunakan analisis data deskriptif kualitatif yaitu proses atau langkah-langkah yang digunakan untuk menganalisis data dengan cara mendeskripsikan atau menggambarkan data yang telah dikumpulkan sebagaimana adanya tanpa bermaksud membuat kesimpulan yang berlaku untuk umum atau generalisasi. (Sugiyono, $2011: 207$ )

\section{HASIL PENELITIAN DAN PEMBAHASAN Hasil Penelitian}

Penelitian ini dilakukan di Lembaga-lembaga PAUD/TK di Kota Mataram pada bulan Oktober dan Nopember 2016, dengan sampel penelitian sebanyak 36 orang guru PAUD /TK yang mengajar pada kelompok A dan B. Obyek yang diteliti berupa Alat permainan Edukatif (APE) yang dimiliki dan dimanfaatkan oleh guru TK dalam menstimulasi tumbuh kembang anak. Data yang diperoleh dengan menggunakan instrument penelitian yang telah disiapkan 
diperoleh dua data dasar berkait dengan identifikasi APE yang digunakan untuk pengembangan motorik halus anak yakni (1) kepemilikan dan frekuensi pemanfaatannya, (2) strategi dan indicator motorik halus anak yang distimulasi dengan memanfaatkan APE yang dimiliki. Sajian data dari masing-masing bagian adalah sebagai berikut :

\section{Kepemilikan dan Frekuensi pemanfaatan APE.}

Data kepemilikan dan ketersediaan alat permainan edukatif untuk stimulasi tumbuh kembang anak khususnya pengembangan motorik halus masingmasing lembaga PAUD/TK telah memilikinya. Bila ditinjau dari segi rasio antara jumlah anak dengan jumlah APE yang dimiliki masih tergolong kurang. Disamping itu dalam pemenfaatan APE untuk pengembangan motorik halus belum tampak pendidik atau guru meracang dan mempersiapkan serta memfasilitasi anak agar kegiatan atau permainan yang dilakukan anak dapat menstimulas perkembangan motorik halus anak.

Kepemilikan masing-masing lembaga yang diteliti memiliki APE yang dapat dimanfaatkan untuk stimulasi tumbuh kembang anak hanya saja pemnafaatannya untuk stimulasi tumbuh kembang anak masih kurang dan belum maksimal dan frekuensi pemanfaatannya sangat bergantung pada kesapan dan kemampuan guru dalam stimulasi tumbuh kembang anak secara simultan dan berkesinambungan. Data yang menunjukan bahwa kepemilikan APE untuk stimlasi tumbuh kembang anak khususnya aspek

motorik halus dimliki oleh setiap lembaga hanya pemanfaatannya yang kurang optimal dan belum merancang strategi agar dapat menstimulasi tmbuh kembang motorik halu anak. Data pemanfaatan APE untuk stimulasi tumbuh kembang anak dapat dilihat pada tabel nomor 1 dibawah ini:

\section{Tabel 1. Data Hasil Identifikasi Pemanfaatan APE untuk Pengembangan Motorik Halus di PAUD/TK di Kota Mataram tahun 2016.}

\begin{tabular}{|l|l|ll|l|l|}
\hline \multirow{2}{*}{ NO } & \multirow{2}{*}{ JENIS ALAT PERMAINAN EDUKATIF (APE) } & \multicolumn{3}{|c|}{ Pemnafaatan } & Tot \\
\cline { 3 - 6 } & & \multicolumn{1}{|c|}{ sering } & \multicolumn{1}{|c|}{ Kadng2 } & jarang & \\
\hline 1 & Platisin untuk dibentuk & $18 / 50 \%$ & $18 / 50 \%$ & - & 36 \\
\hline 2 & Playdog dimanfaatkan sesuai dengan tema & $12 / 33,3 \%$ & $24 / 66,7$ & - & 36 \\
\hline 3 & Bahan alam (pasir, serbuk gergaji) & $30 / 83,3 \%$ & $4 / 11,1 \%$ & $2 / 5,6 \%$ & 36 \\
\hline 4 & Meronce manic-manik & $26 / 72,2 \%$ & $10 / 27,8 \%$ & - & 36 \\
\hline 5 & Balok-balok & $4 / 11,1 \%$ & $24 / 66,7 \%$ & $8 / 22,2 \%$ & 36 \\
\hline 6 & $\begin{array}{l}\text { Fazzel yag ditekakan ada cara mngambil dan } \\
\text { sejenisnya }\end{array}$ & - & $14 / 38,9 \%$ & $22 / 61,1 \%$ & 36 \\
\hline 7 & $\begin{array}{l}\text { Bahan alam (air dan kelengkapannya) untuk } \\
\text { dicampur/ditakardituangkandsbnya. }\end{array}$ & $28 / 77,8 \%$ & $8 / 22,2 \%$ & - & 36 \\
\hline 8 & Kertas Koran untuk disobek/dijadikan bubur kertas & $12 / 33,3 \%$ & $22 / 61,1 \%$ & $2 / 5,6 \%$ & 36 \\
\hline 9 & $\begin{array}{l}\text { bahan alam/buatan sendiri sebagai bahan untuk } \\
\text { dicetak }\end{array}$ & $16 / 44,4 \%$ & $18 / 50 \%$ & $2 / 5,6 \%$ & 36 \\
\hline 10 & Gambar-gambar untuk digunting & $12 / 33,3 \%$ & $24 / 66,7 \%$ & - & 36 \\
\hline 12 & Gambar-gambar untuk dicocok & $28 / 77,8 \%$ & $6 / 16,6 \%$ & $2 / 5,6 \%$ & 36 \\
\hline 13 & Kertas bekas untuk disobek, diremas dsbnya & $32 / 88,8 \%$ & $2 / 5,6 \%$ & $2 / 5,6 \%$ & 36 \\
\hline 14 & $\begin{array}{l}\text { Potongan kertas untuk dianyam dengan cara } \\
\text { tertentu }\end{array}$ & $12 / 33,3 \%$ & $4 / 11,1 \%$ & $20 / 55,6 \%$ & 36 \\
\hline 15 & $\begin{array}{l}\text { Krayon/pensil dengan cara memegang dan } \\
\text { sejenisnya }\end{array}$ & $20 / 55,6$ & $6 / 16,6 \%$ & $10 / 27,8 \%$ & 36 \\
\hline 16 & Penggaris dan pensil untuk membuat garis & $6 / 16,6 \%$ & $20 / 55,6 \%$ & $10 / 27,8 \%$ & 36 \\
\hline 17 & Bahan finger painting dan cara memainkannya & $16 / 44,4 \%$ & $20 / 55,6 \%$ & - & 36 \\
\hline
\end{tabular}


Berdasarkan data pada table 4.1 diatas menunjukan bahwa APE yang banyak digunakan atau dimanfaatkan guru untuk stimulasi tumbuh kembang motorik halus anak adalah bahan alam yang terdiri dari barang bekas seperti kertas bekas yang akan di sobek dan dibuat bubur kertas $88,8 \%$. Tetapi pemanfaatan Koran bekas yang lebih mudah untuk dibentuk dan dikembangkan pada kegiatan dan stimulasi aspek lain maah jarang digunakan $(33,3 \%)$ Bahan alam yang mudah didapat seperti serbuk gergaji, pasir dan air dan sejinisnya $83,3 \%$ guru sangat sering menggunakannya dalam proses pembelajaran. Hal yang juga sering dimanfaatkan guru adalah meronce manic-manik yakni $72,2 \%$, alat mencocok $77,8 \%$.

APE lain yang sesungguhnya sangat besar manfaatnya untuk stimulasi tumbuh kembang motorik halus anak jarang dimanfaatkan guru diantaranya balokbalok, platisin, playdog, gunting penggaris dan bahan pinger painting. APE ini jarang dimanfaatkan oleh guru disebabakan oleh berbagai hal. Yang juga termasuk jarang dimiliki guru atau lembaga adalah APE buatan guru yang dapat digunakan menstimulasi perkembangan otorik halus anak misalnya bahan-bahan yang terbuat dari tanah liat, dari tepung dansebagainya. Fazel juga termasuk APE yang mudah didapat atau mudah dapat dikembangkan oleh guru selain untuk pengembangan kognitif dan emosi anak sangat besar fungsinya untuk pengembangan motorik halus. Finger painting dan pemanfaatan penggaris dan pensil sebagai dasar-dasar untuk pengembangan kemampuan menulis hanya kadang-kadang dimanfaatkan guru, pada hal guru banyak berharaf anak didiknya supaya cepat bisa menulis dengan baik.

\section{Strategi dan indikator motorik halus anak yang distimulasi}

Strategi dan atau cara guru menstimulasi tumbuh kembang motorik halus anak dengan memanfaatkan APE melalui kegiatan bermain masih belum maksimal. Hal ini ditunjukan dengan data yang disampaikan guru berkait dengan pemanfaatan APE, guru memberikan tugas dan mengajak anak melakukan aktifitas yang tunggal tanpa tampak guru mengatur stategi bermain lewat tahapan atau cara memainkan APE tertentu untuk mencapai tujuan perkembangan anak. Kegiatan main yang dilakukan guru masih berupa tugas dan atau anak mengerjakan sesuatu sesuai dengan contoh yang diberikan guru. Misalnya memanfaatkan bahan alam untuk pengembangan motorik halus kegiatan mainnya berupa "kolase". Kegiatan kolase yang dicanangkan untuk anak tanpa disertai dengan cara-cara mengerjakan atau bermain agar terstimulasi motorik halus yang diharapkan.

Pada kegiatan kolase anak anak hanya diharapkan untuk menempelkan atau menabur tapa ada cara tertentu dimana cara tersebut mengandung makna kegiatan yang dilakukan anak bertujuan menstimulasi indicator atau tpp motorik tertentu. Dari data yang terkumpul Nampak bahwa APE yang dinyatakan sebagai APE untuk stimulasi perkembangan motorik anak lebih dominan dimanfaatkan sebagai alat main yang belum tampak proses pendidikannnya atau dengan kata ain anak menggunakan APE tersebut untuk menyelesaikan tugas saja.

Data yang terkumpul menunjukan seperti platisin digunakan untuk membentuk sesuai dengan ide, membuat playdog dan memainkannya. Bila dilihat dari data terbut menunjukan bahwa penggnaan alat tersebut lebih pada pengembangan kognitif. Bahan alam seperti air, pewarna kegiatan yang dimunculkan lebh pada pengembangan kognitif seperti mencampur warna. Data tentang pengembangan motorik atau tingkat pencapaian perkembangan dan atau indicator yang dikembangkan para responden dominan menyatakan untuk pengembangan kelenturan motorik halus da koordinasi motoirk halus. Dominannya guru menyatakan bahwa kegiatan yang dilakukan dalam pengembangan motorik adalah kelenturan dan koordinasi juga 
belum atau tidak jelas karena tidak disebutkan kelenturan motorik halus mana dan koordinasi motorik halus dengan bagain tubh atau motorik halus yang mana. Ada beberapa APE yang utamanya diperuntukan untuk pengembangan motorik dinyatakan sebagai pengembangan kognitif meniru bentuk memebentuk sesuai dengan imajinasi, memebentuk sesuai dengan pola. Pada dasarnya dari data ini tersirat bahwa guru terutama yang menjadi responden penelitian ini belum optimal menguasai perkembangan motorik halus baik dasar teoritiknya mapun indicator perkembangan motorik halus serta strategi dan tahapan yang dapat dilakukan untuk sitmuasi tumbu kembang motrik halus anak usia dini.

\section{Pembahsan}

Berdasarkan data hasil penelitian diatas kepemilikan APE untuk stimulasi tumbuh kembang motorik halus telah dimiliki oleh lembaga dan dimanfaatkan guru dalam pembelajaran, hanya pemenfaatannya belum maksimal sesuai dengan peruntukannya. Disamping itu rasio antara jumlah anak dengan APE yang dimiliki belum terpenuhi. Dilapangan bila kita amati dan lakukan kunjungan ke TK kondisi ini terlihat nyata tidak terpenuhi ratoa anak dengan jumlah APE yang dimiliki.

Dalam pembelajaran guru lebih dominan memberikan contoh dan kemudian menyuruh anak melakukan sesuai dengan contoh dan pada saat anak mengerjakan sesuai dengan contoh dari guru banyak anak menunggu giliran dan atau guru menjelaskan pada sebagai anak yang akan mengerjakan dan anak yang lain menunggu pejelasan guru untuk kegiatan lain/ berbeda dan atau kegiatan yang sama. Kondisi ini menyebabkan tidak efektifnya pemanfaatan APE yang dimiliki untuk stimulasi tumbuh kembang motorik halus anak. Kondisi ini didukung dengan data hasil penelitian menunjukan bahwa pemanfaatan APE dalam stumulasi tumbuh kembang motorik halus anak tidak jelas peruntukannya atau kegiatan maian yang dicanangkan guru dalam memenfaatkan APE belum jelas aspek dan indicator motorik halus yang dikembangkannya.

Pengembangan aspek motorik halus berdasarkan konsep perkembangan motorik terdiri dari empat aspek yang harus dikembangkan yaitu; kekuatan, kelenturan, koordinasi dan kelincahan. Keempat aspek perkembangan motorik ini dalam pengembangkannya agar maksimal perlu memperhatikan atau menstimulasinya mesti berjenjang dan bertahap mulai dari melatih kekuatan, meningkat melatih kelenturan otot motorik halus.

Capaian kekuatan dan kelenturan sebagai dasar pengembangan koordinasi motorik halus dengan bagian tubuh dan aspek perkembangan yang lain sehingga anak mampu menghasilkan atau mencapai perkembangan yang diharapkan. Bila capaian koordinasi telah matang maka pengembangan selanjutnya adalah pengembangan kelincahan. Capaian kelincahan ditunjukan dengan anak lebih inovatif, kreatif dan produktif. Disarming itu anak dapat memenfaatkan capaian perkembangan membentuk atau melakukan sesuatu dengan lebih variatif.

$$
\text { Pemanfaatan APE dalam }
$$

pengembangan motorik halus lebih dominan menggunakan APE yang berasal dari bahan alam, hal ini menunjukan suatu hal yang baik karena akan dapat menghemaat biaya dan anak dibiasakan untuk memenfaatkan lingkungan sebagai media dan sumber belajar. Anak-anak juga tida menjadi asing dengan lingkungannya. Hanya saja dalam proses pembelajaran guru perlu menegaskan atau membuat rancangan kegiatan bermain yang menunjukan suatu tahapan atau kreteria (SOP) kegiatan main sehingga terjadi stimulasi tumbuh kembang anak terjadi secara sistematik dan berkelanjutan.

Pemanfaatan APE yang kadangkadang dimanfaatkan guru dalam pembelajaran sesuangguhnya merupakan APE yang multi guna dalam stimulasi tumbuh embang anak. Multi gan akan dapat 
terjadi bila pendidik atau guru mampu mengkreat kegiatan main yang membutuhkan proses berpikir dan anak butuh waktu yang cukup untuk menyelesaikan kegiatannya karena kegiatan main menstmulasi tumbuh kembang anak secara simultan.

\section{PENUTUP}

Berdasarkan hasil penelitian dan data yang diperoleh dapat ditarik beberapa kesimulan sebagai berikut : Lembaga PAUD/TK memiliki Alata Permainan Edukatif untuk pengembangan atau stimulasi tumbuh kembang motorik halus anak. 2. Rasio APE untuk pengembangan motorik halus anak belum terpenuhi sehingga guru cenderung dalam pembelajaran memberikan contoh kemudian beberapa atau salah satu anak diminta mengerjakan atau menunjukan kinerjanya bekerja sesuai dengan contoh yang disampai guru, sementara anak yang memperhatikan dan menunggu giliran. 3 . Pemenfaatan APE dalam pengembangan motorik halus lebih sering guru memanfaatkan APE dari bahan alam walaupun APE yang lain dimiliki tetapi pemenfaatannya kadang-kadang dan jarang untuk stimulasi tumbuh kembang motorik halus anak. 4. Kegiatan main atau aktifitas pembelajaran yang dibuat guru dengan memanfaatan APE dalam stimulasi tumbuh kembang motorik halus anak belum tampak anak terstimulasi secara sistematik dan berkelanjutan. 5. Guru menyatakan pengembangan motorik halus lebih pada pengembangan kelenturan dan koordinasi motorik halus dengan aspek atau bagian motorik halus lain, pada hal secara konseptual guru mest mengembangkan aspek motorik halus anak secara sistematik dan berkelanjutan yang mencakup melatih kekuatan, kelenturan, kordinasi dan kelincahan. 6. Pengembangan motorik halus sebagai dasar pengembangan kemampuan anak untuk menulis belum terlaksana dengan maksimal.

Saran yang dapat diberikan merupakan saran tindak kepada : 1. Guru
PAUD/TK, Pendidik atau guru PAUD/TK untuk mengoptimalkan pemanfaatan APE yang dimiliki dalam stimulasi motorik halus anak secara sistematik dan berkelanjutan dengan mendalami konsep perkembangan motorik halus pada anak usia dini agar potensi anak berkembangn secara optimal. Disamping itu para pendidik perlu melakukan kajian dan melatih kepekaan diri dalam stimulasi tmbuh kemabng anak khususnya pada pengembangan motorik halus anak usia dini. 2. Pengelola lembaga PAUD, Para pengelola pendidikan anak usia dii khsusunya TK A dan B, agar merancang kegiatan untuk meningkatkan kemapuan dan kapasitas professional gurunya dan memberikan kesempatan lebih luas agar guru memperoleh kesempatan untuk mengembangkan diri.

\section{DAFTAR PUSTAKA}

Arikunto, S. (2005). Prosedur Penelitian Suatu Pendekatan Praktek, Jakarta: PT. Rineka Cipta.

Decaprio, R. (2013). Aplikasi Teori Pembelajaran Motorik Di Sekolah. Jogjakarta: Diva Press.

Direktorat Pendidikan Anak Usia Dini. (2003). Pembuatan dan Penyelenggaraan Alat Permainan EdukatifAnak Usia 3-6 Tahun. Jakarta: Depdiknas.

Hurlock, E. B. (1998). Perkembangan Anak. Jakarta: Erlangga.

Isjoni. (2011). Model Pembelajaran Anak Usia Dini. Bandung: Alfabeta.

Jatmika, .Y.N. (2012). Ragam Aktivitas Harian Untuk Playgroup. Jogjakarta: Diva Press. 
Kompasiana. (2013). Melatih Kemampuan Motorik Halus Pada Anak-Anak Khusus.

http:/edukasi.kompasiana.com//mel atih-kemampuan-motorik-haluspada-anak-anak-khusus523910.html.29/01/2013

Ditjen Olahraga . (2002). Model Pengembangan Motorik Anak Prasekolah. Jakarta: Depdiknas.

Nurliana. 2012. Identifikasi Perkembangan Bahasa Anak Usia 4-5 Tahun Di PAUD Al-Ikhlas Dasan Cermen Tahun Pelajaran 2012-2013. Mataram.

Menteri Pendidikan Nasional R I. (2009). Peraturan Menteri Pendidikan Nasional Republik Indonesia Nomor 58 Tentang Standar Pendidikan Anak Usia Dini.

Sugiyono. (2011). Metode Pnelitian Kualitif-Kualitatif dan $R \& D$. Bandung: CV. Alfabeta.

Susanto, A. (2011). Perkembangan Anak Usia Dini, Edisi Pertama. Jakarta: Kencana.

Wiyani, N. A., Barawi. (2012). Format PAUD: Konsep, Karakteristik, \& Implementasi Anak Usia Dini. Jogjakarta: AR-Ruzz Media.

Zaman, B., dkk. (2007). Media Dan Sumber Belajar TK. Jakarta: Universitas Terbuka. 